Vol. 14 (2005): 377-388.

\title{
Efficacy of imazamox in imidazolinone-resistant spring oilseed rape in Finland
}

Anna-Leena Haukkapää

Department of Applied Biology, PO Box 27, FI-00014 University of Helsinki, Finland, e-mail: anna-leena.haukkapaa@helsinki.fi

Sanni Junnila

MTT Agrifood Research Finland, Plant Protection, FI-31600 Jokioinen, Finland

Christian Eriksson

MTT Agrifood Research Finland, Data and Information Services, FI-31600 Jokioinen, Finland

Unto Tulisalo, Mervi Seppänen

Department of Applied Biology, PO Box 27, FI-00014 University of Helsinki, Finland

\begin{abstract}
Imidazolinonies (IMIs) are a group of herbicides inhibiting acetolactate synthase (ALS) activity. They control the growth of many broadleaved weeds and annual grass species. Herbicide resistance against imidazolinonies has been transferred in some crop species, for example in Brassica napus. IMI-resistant oilseed rape cultivars have been developed by a mutation in ALS. They have been on the market for a few years, especially in North America. To determine if imazamox, an imidazolinone herbicide, and IMI-resistant oilseed rape cultivars are suitable for cultivation in Finland, we conducted four herbicide trials in three locations. We found, that imazamox had no negative effect on yield or oil quality characters of IMI-resistant oilseed rape. Some transient chlorosis was observed immediately after the treatment, but it was not apparent after a few days. The effects of imazamox against the most troublesome weeds in oilseed field in Finland, Chenopodium album and Galium spurium, were very good. Imazamox had good or moderate effects on Stellaria media, whereas its effects on Viola arvensis, Lapsana communis and Fallopia convolvulus were insufficient. If the total weed number was high or the emergence of oilseed rape was slow, the application of imazamox increased the yield of oilseed rape compared to untreated control. Our results suggest that imazamox is a good alternative in controlling weeds for Finnish oilseed fields. Therefore, it would be beneficial to transfer the IMI-resistance into Finnish oilseed and turnip rape lines.
\end{abstract}

Key words: acetolactate synthase, herbicide resistance, imidazolinone herbicides, oilseed rape, weeds 


\section{AGRICULTURAL AND FOOD SCIENCE}

Haukkapää, A.-L. Efficacy of imazamox in spring oilseed rape

\section{Introduction}

Since the early 1970s spring turnip rape (Brassica rapa L.) and oilseed rape (Brassica napus L.) have established their important roles among annual field crops in Finland. In addition to the food and non-food use, they can break the one-sided crop cereal rotations; for this reason their value as a preceding crop in the crop rotation is high. In the last two decades the acreage of cultivated turnip and oilseed rape in Finland has been approximately 60,000 hectares (Ministry of Agriculture and Forestry 2003).

In order to produce good quality oil and meal, the oil milling industry has strict quality parameters for the raw material. One such parameter is a low content of weed seeds (under $3 \%$ ), given that weed seeds both lower the quality of oil and make the processing difficult. Currently, development of new strategies for weed management in oilseed production is necessary, since one of the widely used predrilling herbicide, trifluraline, is planned to be taken off the market leaving only one alternative herbicide (Ministry of Agriculture and Forestry 2003). A potential solution for the problem is the incorporation of herbicide resistance into the genome of oilseed varieties (Mazur and Falco 1989, Burnside 1992).

Herbicide-resistant crops have been developed by conventional plant breeding for resistance to imidazolinones (IMIs), sethoxydin and triazines and through genetic engineering for resistance to bromoxynil, glyphosate, glufosinate, sulfonylureas and 2,4-D (Monaco et al. 2002). In oilseed rape, the most important forms of herbicide resistance are transgenic approaches, such as glyphosate resistance (Roundup Ready ${ }^{\mathrm{TM}}$ ) and glufosinate resistance (Liberty Link ${ }^{\top \mathrm{M}}$ ), and imidazolinone resistance (IMI-resistance). In the latter case, the resistance trait has been introduced by classical breeding methods (Monaco et al. 2002).

IMI-resistance in oilseed rape was developed by exposing oilseed rape microspores to ethylnitrosourea resulting in mutation of the acetolactate synthase (ALS) (EC 4.1.3.18) gene (Swanson et al. 1989). The target enzyme for IMI herbicides is
ALS or acetohydroxyacid synthase (Shaner et al. 1984, Stidham 1991, Vaughn and Duke 1991, Dekker and Duke 1995). The enzyme catalyzes the production of the branched chain amino acids: valine, leucine and isoleucine (Umbarger 1978, Shaner et al. 1984). The reactions, which ALS catalyzes, are: 1) 2 pyruvate $\rightarrow$ acetolactate $+\mathrm{CO}_{2}$ and 2) pyruvate $+\alpha$-ketobutyrate $\rightarrow$ acetohydroxybutyrate $+\mathrm{CO}_{2}$ (Singh et al. 1988). The biosynthesis of branched chain amino acid occurs in chloroplasts (Monaco et al. 2002). When valine, leucine and isoleucine production is inhibited by imidazolinones, plant growth decreases and is followed by plant death (Shaner et al. 1984, Dekker and Duke 1995).

IMI resistant cultivars have been on the market for a few years, especially in North America (Clearfield $^{\mathrm{TM}}$ and $\mathrm{SMART}^{\mathrm{TM}}$ ). In addition to oilseed rape, IMI-resistant cultivars have been developed in wheat, corn, rice, sugar beet, sunflower, sugarcane and soybean (Lovell et al. 1996, Monaco et al. 2002, Poston et al. 2002).

The imidazolinone herbicides were developed in the 1980s (Los 1987, Shaner 1991). Their mechanism of action is similar to sulfonylureas, the very commonly used herbicides in Finland. Both herbicide groups inhibit ALS (Chafleff and Mauvais 1984, Shaner et al. 1984). Chemically, these herbicides are different (Stidham 1991). The other ALSinhibitors are triazolopyrimidine sulfonanilides and pyrimidinylthiobenzoates (Tranel and Wright 2002). In imidazolinones, the chemical group with an imidazolinone ring is bonded to an aromatic ring (Stidham 1991). There are several subcompounds in this group, such as imazaquin, imazethapyr and imazamox (Monaco et al. 2002). Due to their efficiency and favourable health and environmental characteristics, such as low mammalian toxicity and low application rates, imidazolinones are a popular group of herbicides (Mazur et al. 1987, Bernasconi et al. 1995).

Although imidazolinonies are not yet used in Finland, they should be considered as alternative herbicides for rapeseed. Therefore, their suitability for use in Finland should be tested. Some preliminary trials were made with IMI-resistant Canadian oilseed rape cultivars in 2001 in Tuusula, Finland. 
Vol. 14 (2005): 377-388.

On the basis of these trials, the Canadian cultivars were found to be late maturity types, but they were well suited for testing imidazolinonies on the Finnish weed flora. The objective of this study was to investigate the potential use of IMI-resistant rapeseed cultivars in Finland: the effect of imidazolinone on weeds, the phytotoxicity of imazamox on IMI-resistant Canadian cultivars and the proper application rates of imazamox.

\section{Material and methods}

\section{Field experiments}

The effect of imazamox on dicotyledon weeds and on oilseed rape tolerance was investigated in field trials during 2002 and 2003. In both years, the trials were conducted in two locations: 2002 at Anttila Experimental Farm, Tuusula (Exp 1) and at Jokioinen, MTT Agrifood Research Finland (Exp 2); and 2003 at Viikki Experimental Farm, University of Helsinki (Exp 3) and at Jokioinen (Exp 4). The variety used in these trials was IMI-resistant oilseed rape, Hylite $243 \mathrm{cl}$ (Advanta). The exception was Exp 1, where IMI-resistant Hylite $215 \mathrm{cl}$ (Advanta) was used. The experimental design was randomized complete block with three (Exp 1) or four (Exp 2-4) replicates. The herbicide used was imazamox (Raptor ${ }^{\circledR}$, a.i. ammonium salt of 2[4,5-dihydro-4-methyl-4-(1-methylethyl)-5-oxo1H-imidazol-2-yl]-5-(methoxymethyl)-3-pyridinecarboxylic acid at $40 \mathrm{~g}^{-1}$, BASF Corporation, USA). The application rates of imazamox were 30

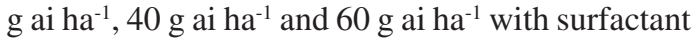
Super Biokiinnite at $0.25 \%(\mathrm{v} / \mathrm{v})$ (Mildola Ltd., Finland) and $30 \mathrm{~g}$ ai ha ${ }^{-1}$ without surfactant. The control plot was left untreated. The plot sizes were from 10.96 to $25.2 \mathrm{~m}^{2}$ (12.5 $\mathrm{cm}$ between rows). The trials were sown on 8 May 2002 (Exp 1 and 2) and on 23 (Exp 4) and 26 (Exp 3) May 2003. Imazamox was applied when oilseed rape was at 3 to 4-leaf stage (BBCH 13-14) (Hack et al. 1992). The application was made by using tractor-mounted sprayer in Tuusula and hand-held sprayer in Jokioinen and Viikki at 2001 ha $^{-1}$.

\section{Field observations}

During the growth season observations of growth (emerging and flowering date, plant height, days to end flowering, lodging and days to mature) were made in Exp 1 and 3. The phytotoxicity effect of imazamox on spring oilseed rape was observed visually three times after the treatment. In addition, the effect of the herbicide on dicotyledon weeds was observed visually two times after the treatment. Phytotoxicity assesments were made in all trials and effects on weeds were assessed in Exp 2 and 3.

\section{Weed counting and dry weight measurements}

The number of dicotyledon weeds per $\mathrm{m}^{2}$ was counted and the dry weights determined 34-38 days after the herbicide treatment (DAT). An exception was Exp 1, where the counting of weeds was made 9 DAT. The number of weeds on a total area of $0.5 \mathrm{~m}^{2}\left(2 \times 0.25 \mathrm{~m}^{2}\right)$ in Exp 1 and 3 and 1.0 $\mathrm{m}^{2}\left(2 \times 0.5 \mathrm{~m}^{2}\right)$ in Exp 2 and 4 was determined in each plot.

\section{Yield and chemical analysis}

After maturation, yield was combine-harvested. The growing times (time from sowing to harvesting) for Exp 1, 2, 3 and 4 were 113, 112, 114 and 111 , respectively. After harvesting, seed yield $(\mathrm{kg}$ ha $\left.^{-1}\right)$, seed purity (\%) and 1000 seed weight $(\mathrm{g})$ were measured.

Oil-, protein-, chlorophyll- and fatty acidanalyses were carried out from Exp 1 and 3. For chemical analysis, samples were pooled between replicates. The aim of the chemical analysis was to verify that chemical composition remained unchanged. The oil content was measured by NMR (nuclear magnetic resonance spectrometry, Bruker NMS 110 minispec, Germany) and the protein and chlorophyll were measured by NIR (near infrared spectrometry, Perten DA 7000, Sweden). Both 
Haukkapää, A.-L. Efficacy of imazamox in spring oilseed rape

analyses were made from whole seed samples. The fatty acids were analysed by gas chromatograph (HP 5890, USA). The preparation of fatty acid samples was done according to the protocol of ISO 5509/ISO 5508.

\section{Statistical analyses}

The experimental design in all the four field experiments was the randomized complete block design with three or four blocks in which the five treatments (four herbicides and untreated plot) were randomized to plots within each block separately. Variability in the measurements was unequal in the different experiments and therefore each experiment was analysed separately. Statistical analyses of the data were based on the following mixed model:

$$
Y_{i j}=\mu+b_{i}+T_{j}+\varepsilon_{i j}
$$

where $Y_{i j}$ is the response for block i and treatment $\mathrm{j} ; \mu$ is the overall mean; $b$ is the random block effect; $T$ is the fixed effect of treatment; $\varepsilon$ is the random error term. The random effects $b_{i}$ and $\varepsilon_{i j}$ are assumed to be mutually independent and normally distributed with zero means and variances $\sigma_{b}^{2}$ and $\sigma_{\varepsilon}^{2}$ respectively. The models were fitted with use of the residual maximum likelihood (REML) estimation method. The degrees of freedom were computed by a method described by Kenward and Roger (1997). Analyses were performed by the MIXED procedure of the SAS/STAT software (Littell et al. 1996). The residual analyses were carried out to check the assumptions of the models. The residuals were checked for normality using a box plot (Tukey 1977) and were also plotted against the fitted values. Comparisons of the treatments were made by two-sided t-type tests. Number and dry weight of the species Chenopodium album, Viola arvensis and Lapsana communis, total number of weeds and seed purity were non-normally distributed. To obtain normality logarithmic transformations were used for the number of C. album, V. arvensis, L. communis and total weeds, as well as for the dry weight of $V$. arvensis.
Instead, square root transformation was applied for the dry weight of $C$. album and for the total number of weeds and arcsine transformation for the seed purity. The growth time observations in Exp 1 and 3 were analysed separately by using Agrobase $^{\text {TM}}$ - program (Mulitze 1991).

\section{Results}

\section{Field observations}

Imazamox treatments did not affect oilseed rape flowering time, height, maturation, or late-season lodging (data not shown). The only statistically significant difference was observed in percentage of lodging at the end of flowering in Exp 1. These differencies were not, however, a result of imazamox treatment since there were no correlations between treatments and the rate of lodging. Chlorosis was observed in oilseed rape 1 to $3 \mathrm{DAT}$, especially in the treatments $\left(30,40\right.$ and $60 \mathrm{~g}$ ai ha- $\left.{ }^{-1}\right)$ with surfactant (Table 1). If the first phytotoxicity observation was delayed to 7 DAT (Exp 3), no symptoms were observed.

Visual observations of the effect of imazamox on dicotyledon weeds were observed in Exp 2 and 3 (Table 1). All imazamox treatments performed well in Exp 3, whereas the low rate did not appear to be adequate in $\operatorname{Exp} 2$.

\section{Weed counting and dry weight measurements}

The decrease in dicotyledon weed number was noteable, when the highest dose of imazamox (60 g ai ha ${ }^{-1}+$ surfactant) was used in Exp 2 (Table 2). The application of imazamox inhibits the function of acetolactate synthase in plants relatively fast, resulting in rapid growth retardation. Despite of the rapid growth retardation, the appearance of lethal symptoms and mortality in sensitive plants takes place slowly (Dekker and Duke 1995). Due 
Vol. 14 (2005): 377-388.

Table 1. Effect of imazamox on visual assessments of oilseed rape injury and weed control.

\begin{tabular}{|c|c|c|c|c|}
\hline Treatment & $\begin{array}{c}\text { Phytotoxicity } \\
1\end{array}$ & $\begin{array}{c}\text { Phytotoxicity } \\
2\end{array}$ & $\begin{array}{c}\text { Phytotoxicity } \\
3\end{array}$ & $\begin{array}{c}\text { Effect on } \\
\text { weeds }\end{array}$ \\
\hline \multicolumn{5}{|l|}{ Tuusula 2002} \\
\hline Untreated & 0 & 0 & ND & ND \\
\hline $60 \mathrm{~g}$ ai ha ${ }^{-1}+\mathrm{s}$ & 5 & 0 & ND & ND \\
\hline $40 \mathrm{~g}$ ai ha ${ }^{-1}+\mathrm{s}$ & 5 & 0 & ND & ND \\
\hline $30 \mathrm{~g}$ ai ha $\mathrm{ha}^{-1}+\mathrm{s}$ & 5 & 0 & ND & ND \\
\hline $30 \mathrm{~g}$ ai ha- & 5 & 0 & ND & ND \\
\hline \multicolumn{5}{|l|}{ Jokioinen 2002} \\
\hline Untreated & 0 & 0 & 0 & 0 \\
\hline $60 \mathrm{~g}$ ai ha ${ }^{-1}+\mathrm{s}$ & 3 & 0 & 0 & 86 \\
\hline $40 \mathrm{~g}$ ai ha $\mathrm{ha}^{-1}+\mathrm{s}$ & 3 & 0 & 0 & 83 \\
\hline $30 \mathrm{~g}$ ai ha ${ }^{-1}+\mathrm{s}$ & 3 & 0 & 0 & 70 \\
\hline $30 \mathrm{~g}$ ai ha- ${ }^{-1}$ & 0 & 0 & 0 & 65 \\
\hline \multicolumn{5}{|l|}{ Helsinki 2003} \\
\hline Untreated & 0 & 0 & 0 & 0 \\
\hline $60 \mathrm{~g}$ ai ha $\mathrm{ha}^{-1}+\mathrm{s}$ & 0 & 0 & 0 & 88 \\
\hline $40 \mathrm{~g}$ ai ha ${ }^{-1}+\mathrm{s}$ & 0 & 0 & 0 & 83 \\
\hline $30 \mathrm{~g}$ ai ha-1 $+\mathrm{s}$ & 0 & 0 & 0 & 85 \\
\hline $30 \mathrm{~g}_{\text {ai ha }} \mathrm{h}^{-1}$ & 0 & 0 & 0 & 85 \\
\hline \multicolumn{5}{|l|}{ Jokioinen 2003} \\
\hline Untreated & 0 & 0 & 0 & ND \\
\hline $60 \mathrm{~g}$ ai ha ${ }^{-1}+\mathrm{s}$ & 3 & 3 & 0 & ND \\
\hline $40 \mathrm{~g}^{\text {ai ha }} \mathrm{ha}^{-1}+\mathrm{s}$ & 3 & 3 & 0 & ND \\
\hline $30 \mathrm{~g}$ ai ha ${ }^{-1}+\mathrm{s}$ & 3 & 3 & 0 & ND \\
\hline $30 \mathrm{~g}$ ai ha ${ }^{-1}$ & 2 & 2 & 0 & ND \\
\hline
\end{tabular}

$\mathrm{s}=$ surfactant $0.25 \%(\mathrm{v} / \mathrm{v}), \mathrm{ND}=$ no data

Phytotoxicity $=$ effect on $B$. napus L.: scale $0-100,0=$ no injuries $100=$ all dead

Tuusula 2002: phytotoxicity $1=3$ DAT, phytotoxicity $2=13$ DAT

Jokioinen 2002: phytotoxicity $1=1 \mathrm{DAT}$, phytotoxicity $2=6 \mathrm{DAT}$, phytotoxicity $3=13 \mathrm{DAT}$

Helsinki 2003: phytotoxicity1 = 7DAT, phytotoxicity2 = 14DAT, phytotoxicity $3=21$ DAT

Jokioinen 2003: phytotoxicity $1=2 \mathrm{DAT}$, phytotoxicity2 $=7 \mathrm{DAT}$, phytotoxicity $3=14 \mathrm{DAT}$

Effect on weeds: scale 0-100, $0=$ untreated $100=$ all dead

Jokioinen 2002: effect on weeds $=$ 13DAT

Helsinki 2003: effect on weeds $=14$ DAT

to this, the weed counting in Exp 1 was made too early, only 9 DAT. The counting of the weed number of three selected weed species showed, that imazamox has a good effect against C. album, but not against $V$. arvensis or $L$. communis (Table 2). Total weed dry weight tended to decrease for all imazamox treatments (Table 3). In general, low application rate ( $30 \mathrm{~g}$ ai ha $\left.\mathrm{h}^{-1}\right)$ can be recommended, if additive surfactant is used.

More detailed analysis on the abundance of different weed species and on the effect of imazamox on weeds was done in Exp 2 and 4. These two experiments differed significantly in weed number; in Exp 2 the total number was high (Table 4), while numbers were low in Exp 4 (Table 5). The most common weed species were $C$. album (Exp 2) (Table 4) and Lamium purpureum (Exp 4) (Table 5). In both experiments, imazamox was effective against $C$. album, Stellaria media and with a higher dosage against Galium spurium (Tables 4 and 5). Furthermore, the effect of imazamox against Thlapsi arvense was good in Exp 4. Imazamox efficacy was poor for example against $L$. purpureum, L. communis, Fumaria officinalis, Fallopia convolvulus, Erysimum cheiranthoides and Polygonum species. Galeopsis bifida did not suffer 
Haukkapää, A.-L. Efficacy of imazamox in spring oilseed rape

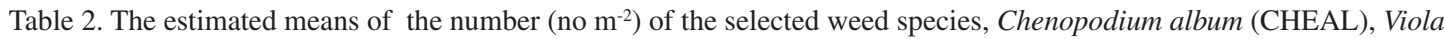
arvensis (VIOAR) and Lapsana communis (LAPCO); the number of total weed 34-38 DAT (Jokioinen 2002, Helsinki 2003 and Jokioinen 2003) and 9 DAT (Tuusula 2002). Numbers in italic refer to the P-values where the different rates of imazamox have been compared to the untreated plot.

\begin{tabular}{|c|c|c|c|c|c|c|c|c|}
\hline Treatment & CHEAL & $\begin{array}{l}P \text {-value } \\
\text { CHEAL }\end{array}$ & VIOAR & $\begin{array}{c}P \text {-value } \\
\text { VIOAR }\end{array}$ & LAPCO & $\begin{array}{l}P \text {-value } \\
\text { LAPCO }\end{array}$ & Total weeds & $\begin{array}{c}P \text {-value } \\
\text { Total weeds }\end{array}$ \\
\hline \multicolumn{9}{|l|}{ Tuusula 2002} \\
\hline Untreated & 47 & & 239 & & 34 & & 339 & \\
\hline $60 \mathrm{~g}$ ai ha- $+\mathrm{s}$ & 38 & 0.46 & 233 & 0.92 & 19 & 0.28 & 310 & 0.74 \\
\hline $40 \mathrm{~g}_{\text {ai }} \mathrm{ha}^{-1}+\mathrm{s}$ & 30 & 0.19 & 195 & 0.53 & 22 & 0.37 & 261 & 0.40 \\
\hline $30 \mathrm{~g}$ ai ha- ${ }^{-1} \mathrm{~s}$ & 18 & $<0.05$ & 237 & 0.98 & 19 & 0.28 & 295 & 0.62 \\
\hline $30 \mathrm{~g}_{\text {ai ha }}{ }^{-1}$ & 33 & 0.28 & 152 & 0.24 & 17 & 0.22 & 213 & 0.19 \\
\hline \multicolumn{9}{|l|}{ Jokioinen 2002} \\
\hline Untreated & 926 & & ND & & 5 & & 1139 & \\
\hline $60 \mathrm{~g}$ ai ha ${ }^{-1}+\mathrm{s}$ & 85 & $<0.05$ & ND & & 5 & 0.88 & 187 & $<0.05$ \\
\hline $40 \mathrm{~g}$ ai ha ${ }^{-1}+\mathrm{s}$ & 225 & $<0.05$ & ND & & 5 & 1.00 & 391 & $<0.05$ \\
\hline $30 \mathrm{~g}$ ai ha- ${ }^{-1} \mathrm{~s}$ & 379 & $<0.05$ & ND & & 5 & 0.88 & 591 & $<0.05$ \\
\hline $30 \mathrm{~g}_{\text {ai ha }} \mathrm{h}^{-1}$ & 679 & $<0.05$ & ND & & 7 & 0.55 & 887 & $<0.05$ \\
\hline \multicolumn{9}{|l|}{ Helsinki 2003} \\
\hline Untreated & 9 & & 6 & & ND & & 27 & \\
\hline $60 \mathrm{~g}_{\text {ai ha }} \mathrm{h}^{-1} \mathrm{~s}$ & 0 & $<0.05$ & 4 & 0.35 & ND & & 5 & $<0.05$ \\
\hline $40 \mathrm{~g}$ ai ha ${ }^{-1}+\mathrm{s}$ & 1 & $<0.05$ & 4 & 0.48 & ND & & 7 & $<0.05$ \\
\hline $30 \mathrm{~g}$ ai ha ${ }^{-1}+\mathrm{s}$ & 1 & $<0.05$ & 5 & 0.64 & ND & & 8 & $<0.05$ \\
\hline $30 \mathrm{~g}_{\text {ai ha }} \mathrm{h}^{-1}$ & 4 & $<0.05$ & 5 & 0.64 & ND & & 10 & $<0.05$ \\
\hline \multicolumn{9}{|l|}{ Jokioinen 2003} \\
\hline Untreated & 32 & & ND & & 4 & & 134 & \\
\hline $60 \mathrm{~g}$ ai ha ${ }^{-1}+\mathrm{s}$ & 0 & $<0.05$ & ND & & 2 & 0.17 & 34 & $<0.05$ \\
\hline $40 \mathrm{~g}$ ai ha $\mathrm{ha}^{-1} \mathrm{~s}$ & 1 & $<0.05$ & ND & & 1 & 0.07 & 51 & $<0.05$ \\
\hline $30 \mathrm{~g}$ ai ha ${ }^{-1}+\mathrm{s}$ & 2 & $<0.05$ & ND & & 1 & 0.07 & 67 & $<0.05$ \\
\hline $30 \mathrm{~g}_{\text {ai ha }}{ }^{-1}$ & 4 & $<0.05$ & ND & & 2 & 0.13 & 77 & $<0.05$ \\
\hline
\end{tabular}

$\mathrm{s}=\operatorname{surfactant} 0.25 \%(\mathrm{v} / \mathrm{v}), \mathrm{ND}=$ no data

from imazamox treatment in Exp 1 (data not shown).

\section{Yield and chemical analysis}

Seed yield $\left(\mathrm{kg} \mathrm{ha}^{-1}\right)$ varied significantly between both years and locations and thus each year and location is analyzed, separately. Herbicide treatments resulted in modest differences in yield and seed purity (Table 6). Generally, in cases when the herbicide treatment significantly increased yield (Exp 2), an increase in seed purity was also noteable. In Exp 1 the seed yield between treatments did not differ significantly from each other; this was due to the luxuriant vegetation of oilseed rape, so that the weeds could not compete with oilseed rape. In Exp 2 the total number of weeds (Table 2) was high resulting in a marked yield decrease in the control treatment (399 $\mathrm{kg} \mathrm{ha}^{-1}$ ) (Table 6). In Exp 2 the best yield result, $1210 \mathrm{~kg} \mathrm{ha}^{-1}$, was achieved when treated with $60 \mathrm{~g}$ ai ha ${ }^{-1}$ imazamox + surfactant. All treatments differed significantly from the untreated control. The seed purity in the untreated control was only $78.9 \%$, wheras it was between 99 and $100 \%$ for all imazamox treatments. There was significantly lower weed pressure in $\operatorname{Exp} 3$ (Table 2) than in Exp 2 and 4 and thus, no effect on yield was observed except when treated with $40 \mathrm{~g}$ ai ha ${ }^{-1}$ imazamox + surfactant. In $\operatorname{Exp} 4$, where the total number of weeds was approximately four-fold compared to Exp 3, notably higher yield was measured in nearly all herbicide application than in untreated control. 
Vol. 14 (2005): 377-388.

Table 3. The estimated means of the dry weight $\left(\mathrm{g} \mathrm{m}^{-2}\right)$ of the selected weed species, Chenopodium album (CHEAL), Viola arvensis (VIOAR) and Lapsana communis (LAPCO); the dry weight of total weed 34-38 DAT (Jokioinen 2002, Helsinki 2003 and Jokioinen 2003)) and 9 DAT (Tuusula 2002). Numbers in italic refer to the P-values where the different rates of imazamox have been compared to the untreated plot.

\begin{tabular}{|c|c|c|c|c|c|c|c|c|}
\hline Treatment & CHEAL & $\begin{array}{l}P \text {-value } \\
\text { CHEAL }\end{array}$ & VIOAR & $\begin{array}{c}P \text {-value } \\
\text { VIOAR }\end{array}$ & LAPCO & $\begin{array}{l}P \text {-value } \\
L A P C O\end{array}$ & Total weeds & $\begin{array}{c}\text { P-value } \\
\text { Total weeds }\end{array}$ \\
\hline \multicolumn{9}{|l|}{ Tuusula 2002} \\
\hline Untreated & 13.95 & & 8.91 & & 6.05 & & 36.3 & \\
\hline $60 \mathrm{~g}^{\text {ai ha }}{ }^{-1}+\mathrm{s}$ & 2.95 & $<0.05$ & 6.92 & 0.40 & 1.62 & $<0.05$ & 14.4 & $<0.05$ \\
\hline $40 \mathrm{~g}$ ai ha ${ }^{-1}+\mathrm{s}$ & 2.62 & $<0.05$ & 5.35 & 0.15 & 1.36 & $<0.05$ & 10.2 & $<0.05$ \\
\hline $30 \mathrm{~g}$ ai ha ${ }^{-1}+\mathrm{s}$ & 1.51 & $<0.05$ & 6.49 & 0.31 & 1.23 & $<0.05$ & 11.7 & $<0.05$ \\
\hline $30 \mathrm{~g}_{\text {ai ha }}{ }^{-1}$ & 2.85 & $<0.05$ & 5.23 & 0.14 & 1.45 & $<0.05$ & 10.7 & $<0.05$ \\
\hline \multicolumn{9}{|l|}{ Jokioinen 2002} \\
\hline Untreated & 296.9 & & ND & & 0.6 & & 326.3 & \\
\hline $60 \mathrm{~g}$ ai ha ${ }^{-1}+\mathrm{s}$ & 4.8 & $<0.05$ & ND & & 0.4 & 0.76 & 9.7 & $<0.05$ \\
\hline $40 \mathrm{~g}$ ai ha ${ }^{-1}+\mathrm{s}$ & 12.9 & $<0.05$ & ND & & 0.8 & 0.61 & 21.8 & $<0.05$ \\
\hline $30 \mathrm{~g}$ ai ha ${ }^{-1}+\mathrm{s}$ & 28.7 & $<0.05$ & ND & & 0.4 & 0.68 & 39.8 & $<0.05$ \\
\hline $30 \mathrm{~g}_{\text {ai ha }} \mathrm{h}^{-1}$ & 58.2 & $<0.05$ & ND & & 0.9 & 0.54 & 70.6 & $<0.05$ \\
\hline \multicolumn{9}{|l|}{ Helsinki 2003} \\
\hline Untreated & 7.03 & & 0.11 & & ND & & 22.64 & \\
\hline $60 \mathrm{~g}$ ai ha ${ }^{-1}+\mathrm{s}$ & 0.00 & $<0.05$ & 0.04 & 0.25 & ND & & 0.12 & $<0.05$ \\
\hline $40 \mathrm{~g}$ ai ha- $\mathrm{ha}^{-1} \mathrm{~s}$ & 0.02 & $<0.05$ & 0.03 & 0.22 & $\mathrm{ND}$ & & 1.10 & $<0.05$ \\
\hline $30 \mathrm{~g}$ ai ha ${ }^{-1}+\mathrm{s}$ & 0.02 & $<0.05$ & 0.10 & 0.93 & ND & & 3.96 & $<0.05$ \\
\hline $30 \mathrm{~g}$ ai ha-1 & 0.05 & $<0.05$ & 0.07 & 0.50 & ND & & 5.71 & $<0.05$ \\
\hline \multicolumn{9}{|l|}{ Jokioinen 2003} \\
\hline Untreated & 17.6 & & ND & & 0.8 & & 39.0 & \\
\hline $60 \mathrm{~g}$ ai ha ${ }^{-1}+\mathrm{s}$ & 0.0 & $<0.05$ & ND & & 0.3 & 0.18 & 1.6 & $<0.05$ \\
\hline $40 \mathrm{~g}$ ai ha ${ }^{-1}+\mathrm{s}$ & 0.0 & $<0.05$ & ND & & 0.2 & 0.13 & 3.4 & $<0.05$ \\
\hline $30 \mathrm{~g}$ ai ha ${ }^{-1}+\mathrm{s}$ & 0.1 & $<0.05$ & ND & & 0.2 & 0.10 & 3.9 & $<0.05$ \\
\hline $30 \mathrm{~g}_{\text {ai ha }} \mathrm{h}^{-1}$ & 0.2 & $<0.05$ & ND & & 0.1 & 0.09 & 4.9 & $<0.05$ \\
\hline
\end{tabular}

$\mathrm{s}=\operatorname{surfactant} 0.25 \%(\mathrm{v} / \mathrm{v}), \mathrm{ND}=$ no data

Chemical analysis of oil quality was carried out for Exp 1 and 3. Imazamox had no effect on any of the quality parameters (data not shown). However, due to a lack of replicates in the chemical analyses (pooled samples), no measure of variability was possible and a discussion of possible treatment effect differences is not plausible.

\section{Discussion}

In this study, we found that imazamox was suitable for controlling weeds in IMI-resistant oilseed rape in Finland. Phytotoxicity symptoms in Canadian oilseed rape cultivars treated with imazamox were transient. These symptoms mainly consisted of chlorosis a few days after the treatment, especially in the treatments with surfactant. None of the imazamox treatments consistently reduced oilseed rape yields. Harker et al. (2000) have also indicated that imazethapyr/imazamox treatment did not lead to noteable crop injuries in oilseed rape. Based on the visual observations and crop yield results, it can be concluded, that the herbicide doses used in the trials, did not have a negative effect on the growth of $B$. napus. The highest dose with a surfactant gave the best result in controlling weeds. Also, the lower doses with a surfactant sufficiently controlled the most sensitive species. Even if the herbicide itself contains a surfactant, the additive improved the effect of imazamox especially in Exp 2 and 4. 


\section{AGRICULTURAL AND FOOD SCIENCE}

Haukkapää, A.-L. Efficacy of imazamox in spring oilseed rape

Table 4. Effect of imazamox on the number $\left(\right.$ no $\left.\mathrm{m}^{-2}\right)$ (a) and the dry weight $\left(\mathrm{g} \mathrm{m}^{-2}\right)$ (b) of the most abundant weed species in Jokioinen 2002. Numbers in italic refer to the percentage of weed number or dry weight compared to control.

\begin{tabular}{|c|c|c|c|c|c|c|c|c|c|c|c|c|}
\hline Treatment & cheal & steme & galsp & lampu & erych & polco & polss & fumof & lapco & gaess & Oth. & Total \\
\hline \multicolumn{13}{|c|}{ a) the number of weeds $\left(\right.$ no $\left.^{-2}\right)$} \\
\hline Untreated & 926 & 93 & 17 & 49 & 12 & 6 & 6 & 6 & 5 & 12 & 7 & 1139 \\
\hline \multirow[t]{2}{*}{$60 \mathrm{~g}$ ai ha ${ }^{-1}+\mathrm{s}$} & 85 & 16 & 2 & 29 & 7 & 10 & 4 & 5 & 5 & 8 & 16 & 187 \\
\hline & 9 & 17 & 12 & 59 & 58 & 167 & 67 & 83 & 100 & 67 & & 16 \\
\hline \multirow[t]{2}{*}{$40 \mathrm{~g}$ ai ha ${ }^{-1}+\mathrm{s}$} & 225 & 45 & 7 & 38 & 12 & 10 & 3 & 8 & 5 & 11 & 27 & 391 \\
\hline & 24 & 48 & 41 & 78 & 100 & 167 & 50 & 133 & 100 & 92 & & 34 \\
\hline \multirow[t]{2}{*}{$30 \mathrm{~g}$ ai ha- ${ }^{-1}+\mathrm{s}$} & 379 & 83 & 13 & 45 & 11 & 6 & 6 & 7 & 5 & 11 & 25 & 591 \\
\hline & 41 & 89 & 76 & 92 & 92 & 100 & 100 & 117 & 100 & 92 & & 52 \\
\hline \multirow[t]{2}{*}{$30 \mathrm{~g}_{\text {ai ha }}{ }^{-1}$} & 679 & 65 & 17 & 52 & 13 & 9 & 9 & 9 & 7 & 14 & 13 & 887 \\
\hline & 73 & 70 & 100 & 106 & 108 & 150 & 150 & 150 & 140 & 117 & & 78 \\
\hline \multicolumn{13}{|c|}{ b) the dry weight of weeds $\left(\mathrm{g} \mathrm{m}^{-2}\right)$} \\
\hline Untreated & 296.9 & 15.4 & 1.6 & 2.7 & 0.9 & 1.0 & 1.0 & 1.6 & 0.6 & 4.2 & 0.4 & 326.3 \\
\hline \multirow[t]{2}{*}{$60 \mathrm{~g}$ ai ha ${ }^{-1}+\mathrm{s}$} & 4.8 & 0.5 & 0.0 & 1.0 & 0.4 & 0.9 & 0.3 & 0.1 & 0.4 & 0.7 & 0.5 & 9.7 \\
\hline & 2 & 3 & 0 & 37 & 44 & 90 & 30 & 6 & 67 & 17 & & 3 \\
\hline \multirow[t]{2}{*}{$40 \mathrm{~g}$ ai ha ${ }^{-1}+\mathrm{s}$} & 12.9 & 0.7 & 0.2 & 1.7 & 0.9 & 1.0 & 0.3 & 0.3 & 0.8 & 1.0 & 2.0 & 21.8 \\
\hline & 4 & 5 & 13 & 63 & 100 & 100 & 30 & 19 & 133 & 24 & & 7 \\
\hline \multirow[t]{2}{*}{$30 \mathrm{~g}$ ai ha ${ }^{-1}+\mathrm{s}$} & 28.7 & 1.8 & 0.5 & 2.3 & 0.7 & 0.5 & 0.5 & 0.3 & 0.4 & 1.6 & 2.5 & 39.8 \\
\hline & 10 & 12 & 31 & 85 & 78 & 50 & 50 & 19 & 67 & 38 & & 12 \\
\hline \multirow[t]{2}{*}{$30 \mathrm{~g}_{\text {ai ha }}{ }^{-1}$} & 58.2 & 2.8 & 0.9 & 2.5 & 0.6 & 0.3 & 0.7 & 0.6 & 0.9 & 1.8 & 1.3 & 70.6 \\
\hline & 20 & 18 & 56 & 93 & 67 & 30 & 70 & 38 & 150 & 43 & & 22 \\
\hline
\end{tabular}

$\mathrm{s}=$ surfactant $0.25 \%(\mathrm{v} / \mathrm{v})$

cheal $=$ Chenopodium album, steme $=$ Stellaria media, galsp $=$ Galium spurium, lampu $=$ Lamium purpureum, erych $=$ Erysimum cheiranthoides, polco = Fallopia convolvulus, polss $=$ Polygonum spp., fumof $=$ Fumaria officinalis, lapco $=$ Lapsana communis, gaess $=$ Galeopsis spp., Oth.= other weeds, Total $=$ total number or dry weight of weeds

The Canadian IMI-resistant cultivars were relatively late-maturing and only matured in this study due to higher than normal temperature accumulation at our study site. For example, in Jokioinen in 2002, the effective temperature sum was $1323.7^{\circ} \mathrm{C}$ at harvesting time, which is $270^{\circ} \mathrm{C}$ more than the average effective temperature sum. However, in Finland, the yield stability of these late-maturing cultivars may be poor under more normal conditions. Therefore, the IMI-resistance should be transferred to oilseed rape cultivars which are well adapted to conditions in Finland.

The most difficult weed species in oilseed field in Finland are C. album and G. spurium (Salonen 2002) and according to this study, imazamox had a very good effect on them. Harker et al. (2000) have also reported about the good effect of imazamox against these species. The competition of weeds with oilseed rape depends upon the establishment of the crop and on the weather during early spring (Knott 1990). Cold weather and drought can delay the emergence of oilseeds, while C. album can utilize these growing conditions and compete well with the oilseed rape (Raatikainen et al. 1971, Weaver et al. 1988). The effect of imazamox against $S$. media was good or moderate, whereas the effect on $V$. arvensis, L. communis and F. convolvulus was not sufficient. In addition to the broadleaved weed species, imidazolinones control many annual grass species, including Avena fatua (Harker et al. 2000, Monaco et al. 2002). In this study only broadleaved weeds were assessed. The 
Vol. 14 (2005): 377-388.

Table 5. Effect of imazamox on the number $\left(\right.$ no $\left.\mathrm{m}^{-2}\right)$ (a) and the dry weight $\left(\mathrm{g} \mathrm{m}^{-2}\right)$ (b) of the most abundant weed species in Jokioinen 2003. Numbers in italic refer to the percentage of weed number or dry weight compared to control.

\begin{tabular}{|c|c|c|c|c|c|c|c|c|c|}
\hline Treatment & cheal & galsp & lampu & steme & lapco & fumof & thlar & Oth. & Total \\
\hline \multicolumn{10}{|c|}{ a) the number of weeds $\left(\right.$ no $\left.\mathrm{m}^{-2}\right)$} \\
\hline Untreated & 32 & 31 & 35 & 21 & 4 & 3 & 4 & 4 & 134 \\
\hline \multirow[t]{2}{*}{$60 \mathrm{~g}$ ai ha ${ }^{-1}+\mathrm{s}$} & 0 & 3 & 23 & 3 & 2 & 0 & 0 & 3 & 34 \\
\hline & 0 & 10 & 66 & 14 & 50 & 0 & 0 & & 25 \\
\hline \multirow[t]{2}{*}{$40 \mathrm{~g}$ ai ha ${ }^{-1}+\mathrm{s}$} & 1 & 8 & 34 & 3 & 1 & 1 & 0 & 3 & 51 \\
\hline & 3 & 26 & 97 & 14 & 25 & 33 & 0 & & 38 \\
\hline \multirow[t]{2}{*}{$30 \mathrm{~g}$ ai ha $\mathrm{ha}^{-1}+\mathrm{s}$} & 2 & 13 & 36 & 7 & 1 & 1 & 0 & 7 & 67 \\
\hline & 6 & 42 & 103 & 33 & 25 & 33 & 0 & & 50 \\
\hline \multirow[t]{2}{*}{$30 \mathrm{~g}_{\text {ai ha }}{ }^{-1}$} & 4 & 14 & 47 & 6 & 2 & 1 & 0 & 3 & 77 \\
\hline & 13 & 45 & 134 & 29 & 50 & 33 & 0 & & 57 \\
\hline \multicolumn{10}{|c|}{ b) the dry weight of weeds $\left(\mathrm{g} \mathrm{m}^{-2}\right)$} \\
\hline Untreated & 17.6 & 7.9 & 3.6 & 7.1 & 0.8 & 0.4 & 0.8 & 0.8 & 39.0 \\
\hline \multirow[t]{2}{*}{$60 \mathrm{~g}_{\text {ai ha }} \mathrm{ha}^{-1}+\mathrm{s}$} & 0.0 & 0.1 & 1.0 & 0.1 & 0.3 & 0.0 & 0.0 & 0.1 & 1.6 \\
\hline & 0 & 1 & 28 & 1 & 38 & 0 & 0 & & 4 \\
\hline \multirow[t]{2}{*}{$40 \mathrm{~g}$ ai ha ${ }^{-1}+\mathrm{s}$} & 0.0 & 0.5 & 2.1 & 0.2 & 0.2 & 0.0 & 0.0 & 0.4 & 3.4 \\
\hline & 0 & 6 & 58 & 3 & 25 & 0 & 0 & & 9 \\
\hline \multirow[t]{2}{*}{$30 \mathrm{~g}$ ai ha ${ }^{-1}+\mathrm{s}$} & 0.1 & 0.8 & 2.0 & 0.4 & 0.2 & 0.0 & 0.0 & 0.4 & 3.9 \\
\hline & 1 & 10 & 56 & 6 & 25 & 0 & 0 & & 10 \\
\hline \multirow[t]{2}{*}{$30 \mathrm{~g}_{\text {ai ha }}{ }^{-1}$} & 0.2 & 1.2 & 2.7 & 0.3 & 0.1 & 0.0 & 0.0 & 0.4 & 4.9 \\
\hline & 1 & 15 & 75 & 4 & 13 & 0 & 0 & & 13 \\
\hline
\end{tabular}

$\mathrm{s}=$ surfactant $0.25 \%(\mathrm{v} / \mathrm{v})$

cheal = Chenopodiun album, galsp = Galium spurium, lampu = Lamium purpureum, steme $=$ Stellaria media, lapco $=$ Lapsana communis, fumof $=$ Fumaria officinalis, thlar $=$ Thlapsi arvense, Oth. $=$ other weeds, Total $=$ total number or dry weight of weeds

symptoms of the susceptible weeds were chlorotic and later necrotic growing points, shortened internodes, and pigment changes, such as purpling and reddening (Monaco et al. 2002). Because imazamox does not kill the weeds immediately (Dekker and Duke 1995), weed biomass decreases more quickly than weed numbers. After imazamox restricts weed growth, the oilseed rape rapidly preempts light and nutrient resources to successfully compete with the weeds.

Until now, the most common herbicide controlling weeds in oilseed fields in Finland has been trifluralin (Ministry of Agriculture and Forestry 2003), soil-applied herbicide, used pre-emergence to control many annual grass and broadleaved weeds (BCPC 1997). Using post-emergence herbicides, such as imazamox, gives an opportunity to control weeds only when it is needed and thus avoid the unnecessary use of herbicides (Blackshaw et al. 1994).

Acknowledgements. The Ministry of Agriculture and Forestry and Maatalouskesko Ltd are thanked for funding this study. We are also grateful to BASF corporation and William Doley. Tarja Niemelä, Arja Wiik, Markku Tykkyläinen, Stefan Selen, Kenneth Ahlqvist, Anna-Kaisa Ojantakanen, Jari Poikulainen, Tellervo Ruoho and Matti Eskola are thanked for their assistance. 


\section{Haukkapää, A.-L. Efficacy of imazamox in spring oilseed rape}

Table 6. The estimated means of the seed yield $\left(\mathrm{kg} \mathrm{ha}^{-1}\right)$, seed purity $(\%)$ and 1000 seed weight $(\mathrm{g})$ in Tuusula 2002, Jokioinen 2002, Helsinki 2003 and Jokioinen 2003. Numbers in italic refer to the P-values where the different rates of imazamox have been compared to the untreated plot.

\begin{tabular}{|c|c|c|c|c|c|c|}
\hline Treatments & $\begin{array}{l}\text { Yield }^{\mathrm{a}} \\
\mathrm{kg} \mathrm{ha}^{-1}\end{array}$ & $\begin{array}{l}P \text {-value } \\
\text { Yield }\end{array}$ & Seed purity & $\begin{array}{c}P \text {-value } \\
\text { Seed purity }\end{array}$ & $\begin{array}{c}1000 \text { seed weight }^{\mathrm{a}} \\
\mathrm{g}\end{array}$ & $\begin{array}{c}P \text {-value } \\
1000 \text { seed weight }\end{array}$ \\
\hline \multicolumn{7}{|l|}{ Tuusula 2002} \\
\hline Untreated & 3193 & & 97.1 & & 3.19 & \\
\hline $60 \mathrm{~g}$ ai ha ${ }^{-1}+\mathrm{s}$ & 3130 & 0.67 & 99.7 & & 3.03 & \\
\hline $40 \mathrm{~g}$ ai ha ${ }^{-1}+\mathrm{s}$ & 3172 & 0.89 & 99.1 & & 3.02 & \\
\hline $30 \mathrm{~g}$ ai ha ${ }^{-1}+\mathrm{s}$ & 3210 & 0.91 & 99.8 & & 2.92 & \\
\hline $30 \mathrm{~g}$ ai ha-1 & 3246 & 0.72 & 99.5 & & 3.05 & \\
\hline \multicolumn{7}{|l|}{ Jokioinen 2002} \\
\hline Untreated & 399 & & 78.9 & & 3.57 & \\
\hline $60 \mathrm{~g}$ ai ha- ${ }^{-1}+\mathrm{s}$ & 1210 & $<0.05$ & 99.5 & $<0.05$ & 3.43 & 0.12 \\
\hline $40 \mathrm{~g}$ ai ha ${ }^{-1}+\mathrm{s}$ & 1081 & $<0.05$ & 99.4 & $<0.05$ & 3.56 & 0.87 \\
\hline $30 \mathrm{~g}$ ai ha ${ }^{-1}+\mathrm{s}$ & 983 & $<0.05$ & 99.6 & $<0.05$ & 3.52 & 0.52 \\
\hline $30 \mathrm{~g}$ ai ha- ${ }^{-1}$ & 971 & $<0.05$ & 99.0 & $<0.05$ & 3.55 & 0.82 \\
\hline \multicolumn{7}{|l|}{ Helsinki 2003} \\
\hline Untreated & 2712 & & 99.1 & & 2.54 & \\
\hline $60 \mathrm{~g}$ ai ha ${ }^{-1}+\mathrm{s}$ & 2574 & 0.31 & 99.5 & & 2.35 & \\
\hline $40 \mathrm{~g}$ ai ha $\mathrm{ha}^{-1}+\mathrm{s}$ & 2372 & $<0.05$ & 99.4 & & 2.49 & \\
\hline $30 \mathrm{~g}$ ai ha-1 $+\mathrm{s}$ & 2650 & 0.64 & 99.8 & & 2.37 & \\
\hline $30 \mathrm{~g}_{\text {ai ha }}{ }^{-1}$ & 2577 & 0.32 & 99.8 & & 2.40 & \\
\hline \multicolumn{7}{|l|}{ Jokioinen 2003} \\
\hline Untreated & 2092 & & 97.7 & & 3.04 & \\
\hline $60 \mathrm{~g}$ ai ha ${ }^{-1}+\mathrm{s}$ & 2366 & $<0.05$ & 98.6 & $<0.05$ & 3.16 & 0.08 \\
\hline $40 \mathrm{~g}$ ai ha $\mathrm{ha}^{-1}+\mathrm{s}$ & 2346 & $<0.05$ & 98.4 & 0.08 & 3.11 & 0.33 \\
\hline $30 \mathrm{~g}$ ai ha- ${ }^{-1}+\mathrm{s}$ & 2284 & 0.08 & 98.0 & 0.40 & 3.07 & 0.66 \\
\hline $30 \mathrm{~g}$ ai ha-1 & 2433 & $<0.05$ & 98.5 & $<0.05$ & 3.12 & 0.25 \\
\hline
\end{tabular}

$\mathrm{s}=\operatorname{surfactant} 0.25 \%(\mathrm{v} / \mathrm{v})$

a in $9 \%$ moisture, $\mathrm{ND}=$ no data

\section{References}

BCPC 1997. The pesticide manual. 11th ed. Tomlin, C.D.S (ed.). British Crop Protection Council, Surrey, UK. p. $1248-1250$.

Bernasconi, P., Woodworth, A.R., Rosen B.A., Subramanian, M.V. \& Siehl, D.L. 1995. A naturally occuring point mutation confers broad range tolerance to herbicides that target acetolactate synthase. The Journal of Biological Chemistry 270: 17381-17385.

Blackshaw, R.E., Kanashiro, D., Moloney, M.M. \& Crosby, W.L. 1994. Growth, yield and quality of canola expressing resistance to acetolactate synthase inhibiting herbicides. Canadian Journal of Plant Science 74: 745751.

Burnside, O.C. 1992. Rationale for developing herbicide-resistant crops. Weed Technology 6: 621-625.

Chafleff, R.S. \& Mauvais, C.J. 1984. Acetolactate synthase is the site of action of two sulfonylurea herbicides in higher plants. Science 224: 1443-1445.

Dekker, J. \& Duke, S.O. 1995. Herbicide-resistant field crops. Advances in Agronomy 54: 69-116.
Hack, H., Bleiholder, H., Buhr, L., Meier, U., Schnock-Fricke, U., Weber, E. \& Witzenberger, A. 1992. A uniform code for phenological growth stages of mono- and dicotyledonous plants. Extended BBCH scale, general. Nachrichtenblatt des Deutschen Pflanzenschutzdienstes 44: 265-270.

Harker, K.N., Blackshaw, R.E., Kirkland, K.J., Derksen, D.A. \& Wall, D. 2000. Herbicide-tolerant canola: weed control and yield comparisons in western Canada. Canadian Journal of Plant Science 80: 647-654.

ISO5508. Animal and vegetable fats and oils. Analysis by gas chromatography of methyl esters of fatty acids. 2 nd ed. International organization for standardization. Switzerland, 1990. 7 p.

ISO5509. Animal and vegetable fats and oils. Preparation of methyl esters of fatty acids. 2 nd ed. International organization for standardization. Switzerland, 2000.11 p.

Kenward, M.G. \& Roger, J.H. 1997. Small sample inference for fixed effects from restricted maximum likelihood. Biometrics 53: 983-997.

Knott, C.M. 1990. Weed control in other arable and field vegetable crops. In: Hance, R.J. \& Holly, K. (eds.). Weed control handbook: principles. Blackwell Scientific, Oxford. p. 329-366. 
Vol. 14 (2005): 377-388.

Littell, R.C., Milliken, G.A., Stroup, W.W. \& Wolfinger, R.D. 1996. SAS system for mixed models. Cary, NC: SAS Institute Inc. $633 \mathrm{p}$.

Los, M. 1987. Synthesis and biology of the imidazolinone herbicides. In: Greenhalg, R. \& Roberts, T.R. (eds.). Pesticides and biotechnology. Blackwell Scientific, Boston MA. p. 35-42.

Lovell, S.T., Wax, L.M., Horak, M.J. \& Peterson, D.E. 1996. Imidazolinone and sulfonylurea resistance in a biotype of common waterhemp (Amaranthus rudis). Weed Science 44: 789-794.

Mazur, B.J., Chui, C.F. \& Smith, J.K. 1987. Isolation and characterization of plant genes coding for acetolactate synthase, the target enzyme for two classes of herbicides. Plant Physiology 85: 1110-1117.

Mazur, B.J. \& Falco, S.C. 1989. The development of herbicide resistant crops. Annual Review of Plant Physiology 40: 441-470.

Ministry of Agriculture and Forestry 2003. Öljykasvistrategia. Työryhmämuistio MMM 2003:8. 53 p.

Monaco, T.J., Weller, S.C. \& Ashton, F.M. 2002. Weed Science principles and practices. 4th ed. Johnwiley \& Sons Inc., New York. 671 p.

Mulitze, D.K. 1991. Agrobase/4 ${ }^{\mathrm{TM}}$, version 1.1, Reference Manual. Agronomix Software Inc., Manitoba, Canada. $257 \mathrm{p}$.

Poston, D.H., Hirata, C.M. \& Wilson, H.P. 2002. Response to acetolactate synthase from imidazolinone-susceptible and -resistant smooth pigweed to ALS inhibitors. Weed Science 50: 306-311.

Raatikainen, M., Raatikainen, T. \& Tinnilä, A. 1971. Rikkakasvit ja niiden torjunta. Kasvinsuojeluseuran julkaisuja no. 46.106 p.

Salonen, S. 2002. Rikkakasvit valtasivat Suomen pellot. Maatilan Pellervo lokakuu 2002. 16 p.
Shaner, D.L. 1991. Mechanism of resistance to acetolactate synthase/acetohydroxyacid synthase inhibitors. In: Caseley, J.C. et al. (eds.). Herbicide resistance in weeds and crops. Butterworth-Heinemann Ltd., Oxford, England. p.187-198.

Shaner, D.L., Anderson, P.C. \& Stidham, M.A. 1984. Imidazolinones-potent inhibitors of acetohydroxyacid synthase. Plant Physiology 76: 545-546.

Singh, B.K., Stidham, M.A. \& Shaner, D.L. 1988. Assay of acetohydroxyacid synthase. Analytical Biochemistry 171: 173-179.

Stidham, M.A. 1991. Herbicides that inhibit acetohydroxyacid synthase. Weed Science 39: 428-434.

Swanson, E.B., Herrgesell, M.J., Arnoldo, M., Sippell, D.W. \& Wong, R.S.C. 1989. Microspore mutagenesis and selection: Canola plants with field tolerance to the imidazolinones. Theoretical and Applied Genetics 78: 525530.

Tranel, P.J. \& Wright, T.R. 2002. Resistance of weeds to ALS-inhibiting herbicides: what have we learned? Weed Science 50: 700-712.

Tukey, J.W. 1977. Exploratory data analysis. Reading MA: Addison-Wesley. $688 \mathrm{p}$.

Umbarger, H.E. 1978. Amino acid biosynthesis and its regulation. In: Snell et al. (eds.). Annual Review of Biochemistry. Paolo Alto, California. Vol. 47. p. 533-606.

Vaughn, K.C. \& Duke, S.O. 1991. Biochemical basis on herbicide resistance. In: Ebing, W. (ed.). Chemistry of plant protection 7. Springer-Verlag, Berlin Heidelberg. p. 142-169.

Weaver, S.E., Tan, C.S. \& Brain, P. 1988. Effect of temperature and soil moisture on time of emergence of tomatoes and four weed species. Canadian Journal of Plant Science 68: 877-886. 
Haukkapää, A.-L. Efficacy of imazamox in spring oilseed rape

\title{
SELOSTUS
}

\section{Imazamoxin vaikutus imidatsolinoni-resistentin kevätrapsin kasvustoon ja esiintyviin rikkakasveihin}

\author{
Anna-Leena Haukkapää, Sanni Junnila, Christian Eriksson, Unto Tulisalo ja Mervi Seppänen \\ Helsingin yliopisto ja MTT ( Maa- ja elintarviketalouden tutkimuskeskus)
}

Imidatsolinonit (IMI:t) ovat herbisidejä, jotka ehkäisevät asetolaktaattisyntetaasi-entsyymin toimintaa. IMI:t tehoavat hyvin useisiin leveälehtisiin rikkakasveihin ja yksisirkkaisiin heiniin. Rapsi (Brassica napus) ei ole luonnostaan resistentti imidatsolinoneille, mutta rapsin IMI-kestävyyttä on voitu lisätä mutaatiojalostuksen avulla. IMI-resistenttejä rapsilajikkeita on ollut jo usean vuoden ajan markkinoilla etenkin Pohjois-Amerikassa. Tässä tutkimuksessa selvitimme, soveltuvatko IMI:t Suomen olosuhteissa käytettäviksi.

Tulostemme mukaan imidatsolinoni-käsittely (imazamox) ei alentanut IMI-resistentin rapsin satoa tai öljyn laatua. Käsittelyn jälkeisinä päivinä rapsissa esiintyi hieman kloroottisuutta, mutta se tasoittui muutamassa päivässä. Imazamox tehosi erittäin hyvin Suomen öljykasvipeltojen yleisimpiin ja taloudellisesti haitallisimpiin rikkakasveihin, jauhosavikkaan (Chenopodium album) ja peltomataraan (Galium spurium), kun taas pelto-orvokkiin (Viola arvensis), linnunkaaliin (Lapsana communis) ja kiertotattareen (Fallopia convolvulus) imazamox ei tehonnut riittävästi. Tulosten perusteella voidaan sanoa, että IMI-resistentit lajikkeet ja imazamox ovat hyvä vaihtoehto Suomen öljykasvipeltojen rikkakasvien torjunnassa. Siksi IMI-kestävyys tulisi siirtää suomalaisiin, aikaisiin rypsi- ja rapsilajikkeisiin. 